Article

\title{
Comprehensive Evaluation of Carbon Emissions for the Development of High-Rise Residential Building
}

\author{
Stephen Y. C. Yim ${ }^{1}$, S. Thomas $\mathrm{Ng}^{2, *}$, M. U. Hossain ${ }^{2}$ and James M. W. Wong ${ }^{3}$ \\ 1 Development and Construction Division, Housing Department, Housing Authority Headquarters, \\ Ho Man Tin, Hong Kong, China; stephen.yim@housingauthority.gov.hk \\ 2 Department of Civil Engineering, The University of Hong Kong, Pokfulam, Hong Kong, China; \\ uzzal@hku.hk \\ 3 Research \& Development, Construction Industry Council, 38/F, COS Centre, 56 Tsun Yip Street, Kwun Tong, \\ Kowloon, Hong Kong, China; jameswong@cic.hk \\ * Correspondence: tstng@hku.hk; Tel.: +852-2857-8556
}

Received: 4 September 2018; Accepted: 17 October 2018; Published: 23 October 2018

\begin{abstract}
Despite the fact that many novel initiatives have been put forward to reduce the carbon emissions of buildings, there is still a lack of comprehensive investigation in analyzing a buildings' life cycle greenhouse gas (GHG) emissions, especially in high-density cities. In addition, no studies have made attempt to evaluate GHG emissions by considering the whole life cycle of buildings in Hong Kong. Knowledge of localized emission at different stages is critical, as the emission varies greatly in different regions. Without a reliable emission level of buildings, it is difficult to determine which aspects can reduce the life cycle GHG emissions. Therefore, this study aims to evaluate the life cycle GHG emissions of buildings by considering "cradle-to-grave" system boundary, with a case-specific high-rise residential housing block as a representative public housing development in Hong Kong. The results demonstrated that the life cycle GHG emission of the case residential building was $4980 \mathrm{~kg} \mathrm{CO} 2 \mathrm{e} / \mathrm{m}^{2}$. The analysis showed that the majority (over $86 \%$ ) of the emission resulted from the use phase of the building including renovation. The results and analysis presented in this study can help the relevant parties in designing low carbon and sustainable residential development in the future.
\end{abstract}

Keywords: greenhouse gases; residential building; life cycle assessment

\section{Introduction}

Climate change has become an unprecedented challenge for humanity. The annual greenhouse gas (GHG) emissions grew on average by 1.0 giga ton carbon dioxide equivalent $\left(\mathrm{GtCO}_{2} \mathrm{e}\right)$ per year from 2000 to 2010 compared to $0.4 \mathrm{GtCO}_{2}$ e per year from 1970 to 2000, and total anthropogenic GHG emissions were the highest in human history reaching $49.0 \mathrm{GtCO}_{2} \mathrm{e} / \mathrm{y}$ in 2010 [1]. These phenomena are primarily due to various human activities, in particular the use of fossil fuels, deforestation, and change in land use [2]. Any delay in stabilizing and reducing the atmospheric $\mathrm{CO}_{2}$ e concentration would only exacerbate the global warming crisis and increase the difficulty to tackle the disastrous consequences in the future [3].

Currently, the building sector represents the single largest contributor to GHG emissions [4,5]. To help reduce GHG emissions, the building sector has an undeniable role to play as buildings worldwide account for up to one-third of the GHG emissions [6]. For subtropical countries and cities like Hong Kong, buildings can contribute to almost $60 \%$ of final energy consumption [7]. Of this, residential buildings take up a significant portion of total energy consumption and hence the GHG emissions, resulting from energy used for construction, operation, and demolition of buildings. 
With a continuous growth in population, a preference for smaller family sizes, and the desire for a more comfortable living environment, the energy demands and GHG emitted from residential buildings in Hong Kong are expected to escalate even further [8].

Establishing pragmatic policy to encourage the building sector to cut down on GHG emissions is clearly an important goal for governments around the world. This is particularly the case for high-density cities not only because there are lots of high-rise buildings but also due to the rather limited opportunities to adopt emerging renewable energy solutions like photovoltaic panels or wind turbines. For Hong Kong, having committed to reducing the energy intensity by at least $25 \%$ by 2030 compared with the 2005 levels, its government has begun to examine the overall life cycle environmental burdens of buildings under their jurisdiction, and the public housing developments would be an ideal starting point as they share around one-third of the entire residential stock in Hong Kong, which is equivalent to 700,000 flats [9]. In 2008, public housing in Hong Kong consumed 6988 million $\mathrm{kWh}$ of electricity or five million tons (Mt) of $\mathrm{CO}_{2} \mathrm{e}$ [7].

Various studies have been conducted to gauge the environmental impacts of buildings. For example, Chen and $\mathrm{Ng}$ [10] proposed factoring in the embodied GHG emissions when assessing the environmental performance of buildings. De Wolf et al. [11] investigated the GHG emissions from 200 recently completed buildings based on the quantities of structural materials (data were based on different design firms) in the United States, without considering the whole life cycle of buildings. A life cycle assessment model was developed to evaluate the environmental impacts of building construction [12]. Peuportier [13] compared the environmental performance of three types of houses located in France, and a sensitivity analysis was performed based on the choice of alternative construction materials, types of heating energy, and transportation using an EQUER tool. Similar studies were conducted in France [14], the Netherlands [15], Japan [16], the United Kingdom [17], and China [18]. Some of the reviews were conducted in assessment of GHG emissions, energy consumption, and other environmental impacts of buildings [19-22].

Focusing on the assessment of GHG emissions generated from the building sector, Suzuki and Oka [23] proposed quantifying the energy consumed and carbon emitted due to the construction, operation, and renovation of office buildings in Japan using input/output tables. On the other hand, Seo and Hwang [24] estimated the life cycle $\mathrm{CO}_{2}$ emissions of different types of residential buildings. Similarly, Bastosa et al. [25] presented a life cycle energy and GHG analysis of three residential building types in Lisbon. Some studies have also focused on the specific stage of the buildings, such as the material level [26,27], building construction [28,29], renovation [30,31], demolition, and end-of-life treatment [32]. The collection of a large variety of data to model a comprehensive assessment is not only time consuming but also, is often impossible. However, a few studies focused on assessing the GHG emissions of the whole building by considering different stages, but excluding the renovation and end-of-life waste treatment [33-37]. Recent reviews also concluded that the occupancy and end-of-life phases are overlooked in most of the life cycle assessment (LCA) studies of building assessment [19,38-40].

In addition, environmental impacts of buildings can significantly vary among the studies depending upon the regions or countries [38,39]. A few studies were conducted on environmental assessment, including GHG emissions of buildings in Hong Kong [12,41,42]. However, these studies have excluded some important aspects in their assessment, e.g., considerations of use, renovation, and end-of-life phases of the building. The aim of this research therefore, is to evaluate the life cycle GHG emissions of high-rise residential building comprehensively by including the construction, use and renovation, and end-of-life phases as a case in Hong Kong. The results of the study can be used as a benchmark for comparing and setting up mitigation measures for new building construction.

\section{Methodology}

The life cycle assessment (LCA) method has been used for assessing the GHG emissions of high-rise public housing blocks in this study. LCA enables the quantification and evaluation of 
environmental impacts of a building [41]. Governed by the ISO 14040 standard [43], an analytical skeleton is applied in this study which consists of four main phases; goal and scope definition, life cycle inventory analysis, life cycle impact assessment, and interpretation.

\subsection{Goal and Scope of Study}

This study aimed to evaluate the GHG emissions (in terms of $\mathrm{CO}_{2} \mathrm{e}$ ) from cradle-to-grave of a public housing block as shown in Figure 1. The GHG emissions are calculated by assessing the GHGs as defined in the Kyoto Protocol of the United Nations Framework Convention on Climate Change (UNFCC), including carbon dioxide $\left(\mathrm{CO}_{2}\right)$, methane $\left(\mathrm{CH}_{4}\right)$, nitrous oxide $\left(\mathrm{N}_{2} \mathrm{O}\right)$, hydro fluorocarbons (HFCs), perfluorocarbons (PFCs), and sulphurhexafluoride $\left(\mathrm{SF}_{6}\right)$ [44,45]. These GHG emissions are converted into $\mathrm{kg}$ or $\mathrm{tCO}_{2} \mathrm{e}$ emissions using the Intergovernmental Panel on Climate Change (IPCC) 100-year global warming potential (GWP) coefficients [46]. In this study, the functional unit was the unit of flat and gross floor area (GFA) of the building, i.e., $\mathrm{m}^{2}$.

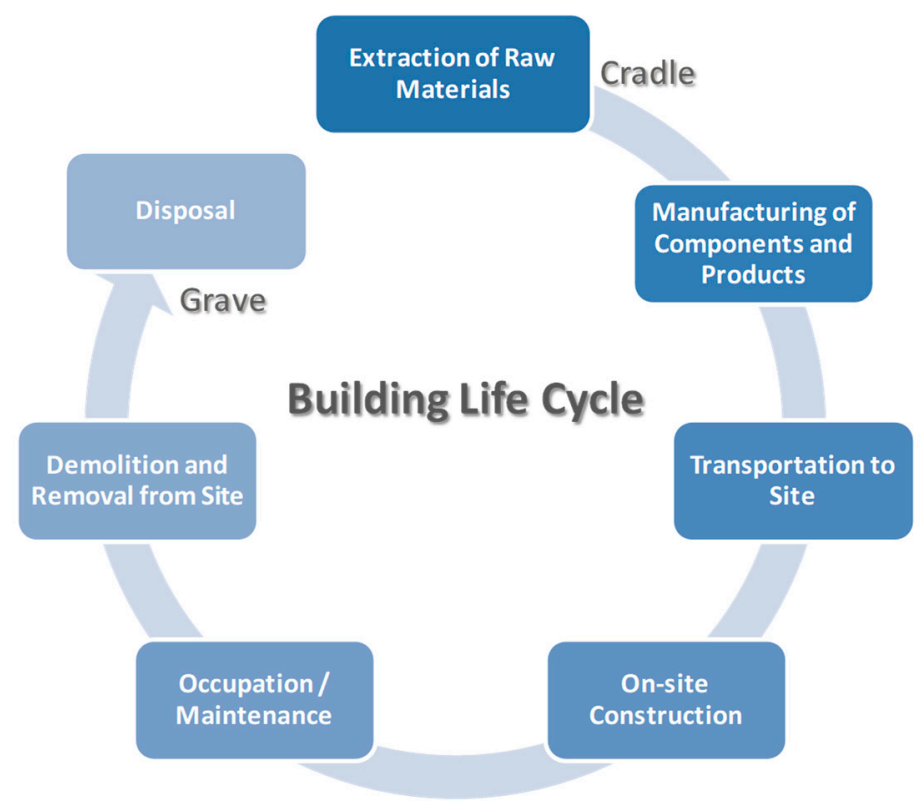

Figure 1. Life cycle process of a building.

A standard housing block design named "New Harmony One" (NH1)—Option 6, as shown in Figure 2, was selected for the analysis and used for setting a benchmark for the life cycle GHG emissions of public residential buildings. The Housing Authority adopted a site specific design approach and the internal floor area since 2004, by applying micro-climate studies at the early planning stage [47]. NH1 is selected as a basis of this study, as such a design can be applied to various sites in Hong Kong on a repetitive basis. Typically, a NH1 block is a reinforced concrete tower of 40 domestic levels which contains 799 flats with a gross floor area of $33,078 \mathrm{~m}^{2}$. The ground floor is used for non-domestic purpose to accommodate the necessary ancillary facilities. There are 16-20 modular flats per floor which are arranged in four groups in a cruciform configuration attached to the central core where building services, lifts, and staircases are located. The compact form of NH1 makes it suitable for use in smaller urban area sites in Hong Kong. 


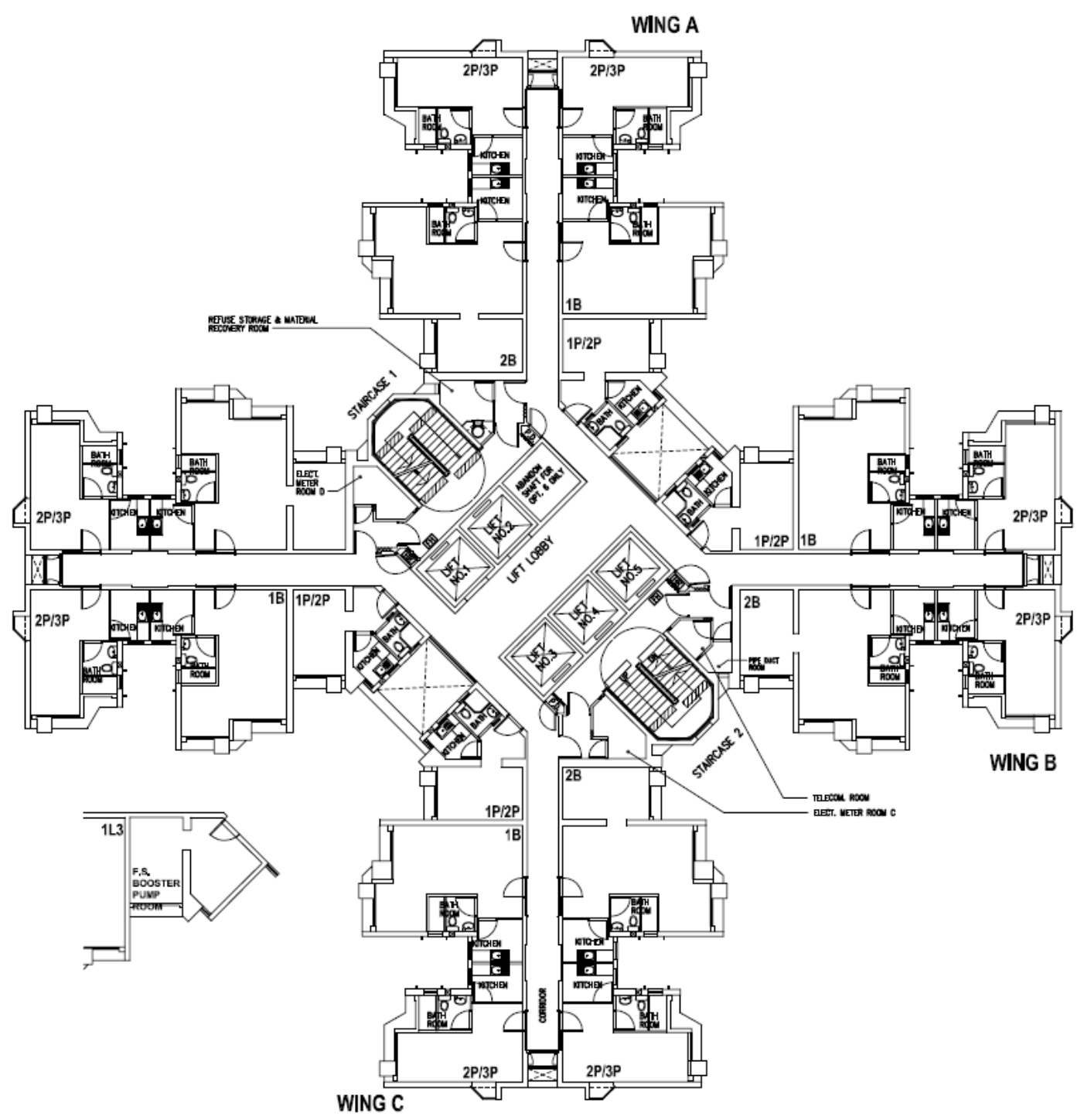

Figure 2. New Harmony One (NH1) residential building design.

The GHG emissions over the building's life cycle are assessed based on their sources and components, so as to evaluate the carbon footprint of the building meaningfully. Based on ISO 21931-1 [48] "Sustainability in Building Construction-Framework for Methods of Assessment of the Environmental Performance of Construction Works-Part 1: Buildings", the scope of a carbon audit study includes eight aspects associated with the following three distinct but interlinked stages: (i) production and construction; (ii) occupation (both energy consumed by tenants and communal installations) and renovation; and (iii) demolition as shown in Table 1. The guidelines provided by this ISO standard were used to derive the equations (Equations (1)-(7)) in this study. In addition, the said method aligns well with the carbon emission estimation model developed by the Hong Kong Housing Department [9], and Equations (1)-(7) were therefore used for the assessment of each individual stage accordingly. These aspects cover the major sources of GHG emissions of a building's life cycle as suggested by Seo and Hwang [24] and Fieldson et al. [49] which form the system boundary of this study. As a result, a "cradle-to-grave" system boundary with the functional unit of $1 \mathrm{~m}^{2}$ of building floor area was considered in this study. The system boundary covers the production and transportation of principal construction materials; the use stage of buildings including the energy consumed by building services equipment and utilities; renovations including the material's production and transportation; waste transportation and disposal; and the end-of-life stage of buildings including the dismantling of buildings, and transportation of waste materials to the disposal sites (Table 1). However, the energy 
and fuel used on site during construction were excluded, as their emissions are minimal compared with the emissions of the entire building's life cycle. For example, the construction processes contribute to only about $2-5 \%$ of the total emissions (except refurbishments, demolition, and waste treatment) [28,50]. Taking into account the quantity and environmental profile, this study initially focused on three major materials, namely concrete, steel, and timber as they are the dominant contributors of embodied carbon of a housing block [51]. An inventory of materials and energy consumed over the sampled building's life cycle is assessed to calculate the associated GHG emissions. However, the inventory given in Table 1 omits non-structural materials and associated emissions over the building's life cycle.

Table 1. Study scope and system boundary of the greenhouse gas (GHG) evaluation.

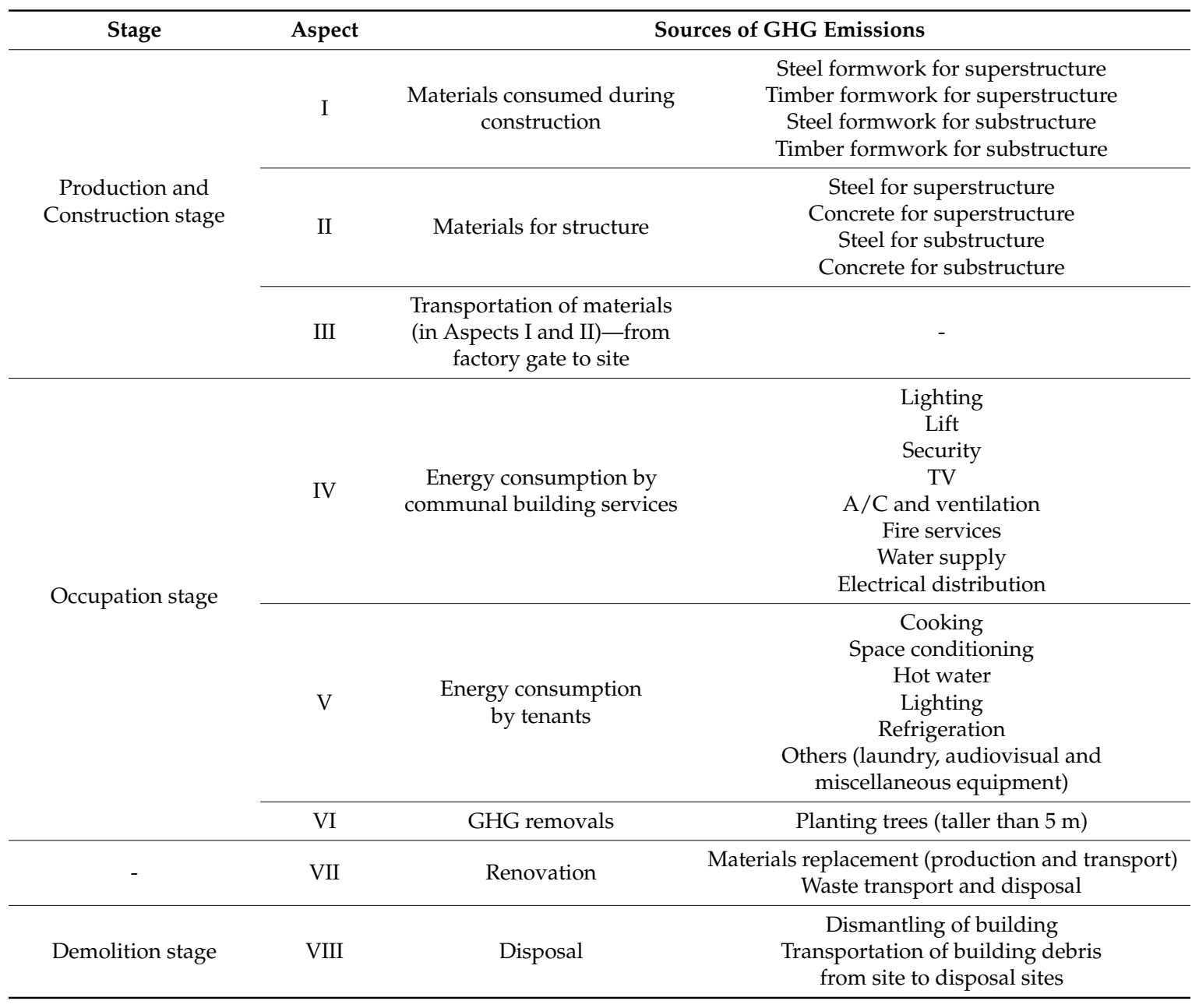

\subsection{Inventory Analysis and Analytical Framework}

\subsubsection{Emissions in the Construction Stage (Aspects I, II, and III)}

The construction process of building follows the NH1 design of construction. As indicated, the GHG emissions of the construction process is excluded from this study, as it contributes to a negligible amount of emissions compared to the total emission associated with building. While the energy used and the consequential GHG emissions over the occupation of a building contribute to the majority of its carbon footprint, a considerable amount of GHG is emitted during the manufacturing and transportation of building materials [6]. Equation (1) calculates the embodied GHG emissions of key building materials consumed during construction and for structure (i.e., Aspects I and II, respectively), including concrete, steel, and formwork. This accounts for $84-95 \%$ of the total materials (structural and non-structural) related GHG emissions for a reinforced concrete framed building [26,52]. 
This measures the GHG emitted from the extraction, processing and manufacturing of building materials [53].

$$
G H G_{m}=\sum_{i=0}^{n} Q_{i} \times F_{i}^{m}
$$

where $G_{H G}$ is the total embodied GHG emissions of concrete, steel, and formwork (in $\mathrm{kg} \mathrm{CO}_{2} \mathrm{e}$ ); $Q_{i}$ is the amount of building material $i\left(\right.$ in $\left.^{3}\right)$; and $F_{i}^{m}$ is the GHG emission factor for building material $i$ (in $\mathrm{kg} \mathrm{CO}_{2} \mathrm{e} / \mathrm{m}^{3}$ ).

The quantities of concrete, steel, and timber employed during the construction of the NH1 housing block were obtained from the tender documents as well as the drawings. Local, regional, and international sources and databases were used to retrieve the GHG emission factors for the selected building materials (Table 2). For example, the GHG emission factor for steel production was extracted from the Inventory of Carbon and Energy (ICE) compiled by Hammond and Jones [54], which is within the range of steel production in China [55]; local concrete production was according to Zhang et al. [56]; and regional (Southern China) timber production was from Zhang [57]. The use of local or regional GHG emission factors for the principal building materials is important for achieving representative results. Therefore, local or regional GHG emission factors for such materials were used in this study.

Table 2. Embodied carbon of materials (unit: $\mathrm{kg} \mathrm{CO}_{2} \mathrm{e} / \mathrm{m}^{3}$ ).

\begin{tabular}{cccc}
\hline References & Timber & Steel & Concrete \\
\hline Hammond and Jones [54] & 468 & $15,210^{\mathrm{b}}$ & 317 \\
Morris [58] & 450 & 14,287 & 326 \\
Eaton and Amato [59] & - & 15,313 & - \\
Zhang et al. [56] & - & - & $426^{\mathrm{c}}$ \\
Zhang [57] & $962^{\mathrm{a}}$ & - & - \\
Alcorn [60] & - & 10,441 & 376
\end{tabular}

Note: a plywood, embodied carbon: $1.78 \mathrm{~kg} \mathrm{CO}_{2} \mathrm{e} / \mathrm{kg}$ in China with the density as of $540 \mathrm{~kg} / \mathrm{m}^{3}$ [57]; ${ }^{\mathrm{b}}$ steel bar and rod, embodied carbon: $1.95 \mathrm{~kg} \mathrm{CO} 2 \mathrm{e} / \mathrm{kg}$ which is within the range of steel production in China (1.72-1.96 kg CO $2 \mathrm{e} / \mathrm{kg}$ steel) according to Jing et al. [55]; non-EU average recycled content: $35.5 \%$; density is assumed as $7800 \mathrm{~kg} / \mathrm{m}^{3}[61] ;{ }^{\mathrm{c}}$ concrete grade is assumed as $32 / 40 \mathrm{MPa}$, embodied carbon: $0.177 \mathrm{~kg} \mathrm{CO} \mathrm{C}_{2} \mathrm{e} / \mathrm{kg}$, density is assumed as $2400 \mathrm{~kg} / \mathrm{m}^{3}$ [61].

Transportation emissions are also an integral part of the LCA study, generated from the transportation of construction materials from cradle-to-gate and from gate-to-site. Aspect III focuses on the latter stage, i.e., the transportation distances from the manufacturing plant to the construction site. The former stage has already been included in the embodied carbon emission factors as shown in Table 2, which embraces all energy required for extraction, manufacturing, and transportation until the materials leave the factory gate. In the case of the NH1 block, $95 \%$ of the building materials can be sourced from Hong Kong or South China, they are therefore transported through the land routes using diesel trucks and by sea [51]. Equation (2) calculates the GHG emissions generated from the transportation of building materials.

$$
G H G_{t}=\sum_{i=0}^{n} \frac{\left(Q_{i}^{l} \times E_{l} \times D_{i}^{l} \times F_{l}^{t}\right)}{5}
$$

where $G H G_{t}$ is the total GHG emissions from fuel combustion of transportation of the key building materials (in $\mathrm{kg} \mathrm{CO}_{2} \mathrm{e}$ ); $Q_{i}^{l}$ is the amount of building material $i$ transported by land (in $\mathrm{m}^{3}$ ), assuming the loading limit per truck is $5 \mathrm{~m}^{3} ; E_{l}$ is the diesel consumption (in liter $/ \mathrm{km} /$ truck), which is $0.325 \mathrm{~L} / \mathrm{km}$; $D_{i}^{l}$ is the total distances of transporting building materials $i$ by land (in $\mathrm{km}$ ), and the distances between the site and the manufacturing plant in Hong Kong and South China are assumed as $20 \mathrm{~km}$ [52] and $250 \mathrm{~km} \mathrm{[62],} \mathrm{respectively;} \mathrm{and} F_{l}^{t}$ is the emission factors of transporting by diesel truck, which is $2.62 \mathrm{~kg} \mathrm{CO}_{2} \mathrm{e} /$ liter [52]. 


\subsubsection{Emissions in the Occupation Stage (Aspects IV, V, VI and VII)}

During the occupation phase, heating and electricity account for the major portion of GHG emissions [63]. For this study, the GHG emissions at the occupation stage are quantified and classified into three aspects, namely: Aspect IV-Energy consumption by communal building services; Aspect V—Energy consumption by tenants; Aspect VI—GHG removals; and Aspect VII—Renovation. Equation (3) is used to simulate the GHG emissions from the energy consumption by communal building services and tenants.

$$
G H G_{o}=\sum_{i=0}^{n}\left(E_{i}^{e} \times F_{e}+E_{i}^{g} \times F_{g}\right) \times 50,
$$

where $G H G_{0}$ is the total GHG emissions due to the energy used over the 50-year building life cycle (in $\mathrm{kg} \mathrm{CO} \mathrm{CO}_{2} \mathrm{e}$ ); $E_{i}^{e}$ and $E_{i}^{g}$ are the annual quantity of electricity and gas consumption for building services system $i$, in $\mathrm{kWh}$ or in gas unit (i.e., 1 unit as registered by the gas meter $=48$ mega joules consumed), respectively; $F_{e}$ and $F_{g}$ are the emission factors of the energy consumed by electricity and gas, respectively, with the territory-wide default values of $F_{e}$ and $F_{g}$ being $0.7 \mathrm{~kg} \mathrm{CO} \mathrm{CO}_{2} \mathrm{e} / \mathrm{kWh}$ and $0.59 \mathrm{~kg} \mathrm{CO} 2 \mathrm{e} /$ unit of gas purchased, respectively [64].

The electricity consumption data for communal building services installations was calculated from the sampled NH1 housing block. However, the energy consumed by tenants of the sampled housing block was not accessible. Therefore, the energy end-use data of the public housing group (in terajoules) as published by the Electrical and Mechanical Services Department [7] was used for the energy use estimation in this study. It was assumed that $80 \%$ of the tenants used electric water heaters while the rest used gas water heaters [65] and $90 \%$ of tenants used gas for cooking [66].

GHG removals are calculated by assessing the respective GHG absorption by the assimilation of $\mathrm{CO}_{2}$ by plants as shown in Equation (4). According to EPD [64], $23 \mathrm{~kg} \mathrm{CO}_{2}$ can be removed by each tree based on Hong Kong's location, woodland types, and estimated density of trees. The figure is applicable to all trees commonly found in Hong Kong which are able to reach at least $5 \mathrm{~m}$ in height. Since this figure is derived as an annual average based on an extended period of time corresponding to the life cycle of the trees, the figure is applicable to trees at all ages.

$$
G H G_{r}=\left(T \times F_{t}\right) \times 50,
$$

where $G H G_{r}$ is the total GHG absorption over the 50-year building life cycle by tree planting (in $\mathrm{kg} \mathrm{CO}_{2} \mathrm{e}$ ); $\mathrm{T}$ is the number of newly planted trees within the building's physical boundary (e.g., within building premises, associated with the surroundings that are used for multipurpose activities including planting trees for a particular housing estate) after the beginning stage of construction which are able to reach at least $5 \mathrm{~m}$ in height; and $F_{t}$ is the GHG removal factor, which is taken as $23 \mathrm{~kg} \mathrm{CO}_{2} /$ tree per annum [64].

In this study, a 50-year service life of a residential block in Hong Kong was considered. As a complex system, buildings would often undergo various changes by means of renovation. Considering the building's service life, typical replacement of principal elements with their number of replacements over the entire life of a building in Hong Kong are shown in Table 3 (adjusted based on Chiang et al. [67]). The production and transport of these materials/elements were included in the LCA. Ecoinvent databases were used for collecting their upstream data, for instance, ceramic tile, emulsion paint, sealing materials, and hardwood doors production. Based on the renovation of typical flats, average per unit $\left(\mathrm{m}^{2}\right)$ was calculated according to Chiang et al. [67]. In addition, the transportation and disposal (in landfills) of materials generated during renovation were also considered in this assessment. 
Table 3. Typical replacement of building elements during renovation in Hong Kong.

\begin{tabular}{ccc}
\hline Element/Material & Service Life (years) & $\begin{array}{c}\text { Number of Replacements over } \\
\text { the Service Life of Building }\end{array}$ \\
\hline Ceramic tiles & 20 & 2 \\
Emulsion paint & 5 & 9 \\
Silicone seal & 10 & 4 \\
Hardwood solid-core doors & 20 & 2 \\
\hline
\end{tabular}

Therefore, the total GHG emissions due to the renovation of the building during its service life can be estimated by Equation (5).

$$
G H G_{R}=\sum_{\text {service life }=50}\left(M_{R} \times N_{R}\right)+T_{M}+D_{L},
$$

where $G H G_{R}$ is the total GHG emissions over the 50-year service life of building (in $\mathrm{kg} \mathrm{CO}_{2} \mathrm{e}$ ); $M_{R}$ is the materials/elements replacement during renovation; $N_{R}$ is the number of replacements of the respective elements/materials; $T_{M}$ is the transport of the materials; and $D_{L}$ is the disposal into landfill.

\subsubsection{Emissions in the Demolition Stage (Aspects VIII)}

According to ISO [68], recycling of steel and concrete should be assessed in the subsequent loop of a building life cycle. Typically, inert wastes generated from buildings are disposed at public fill sites, whereas non-inert waste are dumped into landfills, in Hong Kong. After transporting to off-site sorting facilities, inert materials are crushed and screened to recycle materials. In addition, a certain amount of concrete is recycled [69]. After screening, the remaining inert materials are sent to public fills, while the non-inert materials are disposed at landfills. However, the impacts of recycling and disposal were excluded due to the complexity of different management strategies and the lack of data in Hong Kong. In this study, the GHG emitted during the demolition stage is mainly due to the energy consumption for the machinery operation at the demolition site and the transportation of building debris from the site to disposal sites [23]. It is also assumed that the saving of GHG emissions due to steel and concrete recovery, and the induced GHG emissions of other materials' disposal (whether to public fills or landfills) would be similar, and thus they were excluded from this analysis. Equation (6) serves as the basis to assess the emissions.

$$
G H G_{d}=Q_{d} \times F_{d}+\frac{Q_{d} \times E_{d} \times D_{i}^{l} \times F_{l}^{t}}{5}
$$

where $G H G_{d}$ is the total GHG emissions in the demolition stage; $Q_{d}$ is the amount of building materials to be dismantled or building debris (in $\mathrm{m}^{3}$ ), for transportation of building debris, $5 \mathrm{~m}^{3}$ load per truck is assumed; $F_{d}$ is the emission factor for dismantling a building, which is $17 \mathrm{~kg} \mathrm{CO} \mathrm{CO}_{2} \mathrm{e} / \mathrm{m}^{3}$ according to Nielsen [70]; $E_{d}$ is the diesel consumption (in liter $/ \mathrm{km} /$ truck), which is $0.325 \mathrm{~L} / \mathrm{km} \mathrm{[71];} D_{i}^{l}$ is the total distance for transporting building materials $i$ by land (in $\mathrm{km}$ ) and the distance is taken as $26 \mathrm{~km}$ [52]; and $F_{l}^{t}$ is the emission factors for transportation by diesel truck, which is $2.62 \mathrm{~kg} \mathrm{CO}_{2} \mathrm{e} /$ liter [52].

Therefore, the total GHG emissions over the NH1's building life cycle can be estimated by Equation (7):

$$
G H G_{N H 1}=G H G_{m}+G H G_{t}+\left(G H G_{o}+G H G_{r}+G H G_{R}\right)+G H G_{d}
$$

\subsection{Limitations}

Conducting an environmental assessment of the whole building is complicated due to the differences in materials, associated transportation, diverse considerations at the use stage, lifespan of the building, and different considerations of the end-of-life of the building. Although this study has attempted to include all these in the assessment, several limitations cannot be avoided. For example, 
this study did not consider the contributions of non-structural materials. Waste material (generated during the construction and end-of-life stages) treatments were not considered in this assessment. During the use stage of building, actual energy consumed by tenants is not accessible. Thus, average energy consumption data was collected from the relevant department [7]. Due to the lack of local/regional data, Ecoinvent databases were used for carbon emissions of the replacement materials for the renovation of building. This study only focused on carbon assessment and excluded other impact categories. However, some of the limitations were further discussed and justified in the Discussion section.

\section{Results}

The result of GHG emissions throughout the life cycle of the standard NH1 public housing block, based on Equation (7), is presented in Table 4. Using the data collected and assumptions, the estimated total life cycle GHG emissions of the block are 186,150 $\mathrm{tCO}_{2} \mathrm{e}$ for the NH1 2000 Edition. The GHG emissions intensity of the sampled building is $232.98 \mathrm{tCO}_{2} \mathrm{e} /$ flat or $5.38 \mathrm{tCO}_{2} \mathrm{e} / \mathrm{m}^{2}$ of GFA. Figure 3 shows the distribution of the emissions in various life cycle phases. The operating energy consumption by communal building services and tenants is clearly impacting the environment the most, accounting for about $85.82 \%$ of the emissions. The materials consumed during construction, though emit considerably less GHGs than that in the operation stage, are taking up about $12.69 \%$ of the life cycle emissions. The remaining aspects, including the renovation, transportation of materials, and the disposal of the block are accounted to $1.14 \%, 0.07 \%$, and $0.28 \%$, respectively, of the building's carbon footprint.

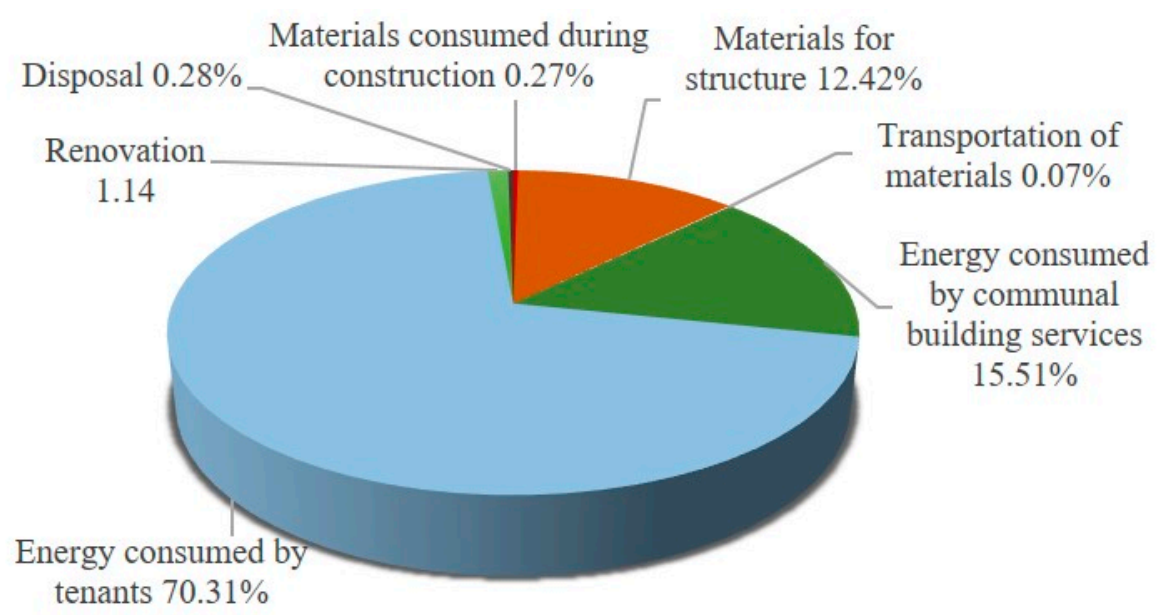

Figure 3. Contribution to the GHG emissions of the sampled housing block.

Hotspots for GHG emissions of building have been highlighted in Figure 3 (i.e., the contribution to GHG emissions). It can be seen that over $85 \%$ of the total GHG emissions is associated with energy consumption of tenants and building services equipment. This supports the results from previous studies $[16,24,72]$. The elements emitting the most significant amount of GHGs are found to be communal lighting and lifts, as well as the energy consumed by tenants for hot water, space conditioning, and refrigeration. This reflects that GHG emitted from a public housing block are strongly dependent not only on the building and occupancy factors such as ventilation and efficiency of appliances, but also on the source of energy. Therefore, it is important to install energy efficient building service equipment, and encourage tenants to use energy efficient appliances to reduce energy consumption and GHG emissions. Apart from reducing the energy consumption and embodied energy in buildings, switching to low carbon fuels and utilizing renewable energy are considered effective in tackling the climate change problem [46]. Materials (including their production and transportation) emit about $13 \%$ of the total emissions. However, it is possible to reduce GHG emissions by sourcing sustainable materials and using low carbon materials. 
During the construction stage, concrete is the dominant building material for the NH1 housing block, not only in terms of quantities but also the embodied carbon. The NH1 housing block studied consumed over $28,600 \mathrm{~m}^{3}$ of concrete, producing over 12 million $\mathrm{kg}$ of $\mathrm{CO}_{2} \mathrm{e}$. Reducing the carbon content of concrete through the manufacturing process is therefore influential. A saving in embodied carbon can be achieved by increasing the proportion of off-site manufacturing of components and/or adopting recycled materials or materials with lower environmental impact [6,52]. For instance, by replacing cement with alternative binding materials (e.g., pulverized fuel ash, ground granulated blast furnace slag, and silica fume) in the concrete mixes can save significant amount of cement and the associated $\mathrm{CO}_{2}$ emissions [51,73]. In addition, the use of alternative or low carbon cement, i.e., eco-glass cement or Portland fly-ash cement, can also considerably reduce the carbon footprint of concrete [74].

The study also estimated the GHG emissions of the residential block according to the latest "Model Client Brief 2010" as presented in Table 4. According to the Hong Kong Energy End-Use Data 2010 provided by the Electrical and Mechanical Services Department of Hong Kong SAR [7], this brief has incorporated the latest development of various communal building services installations. These include the employment of electronic ballasts and two illumination levels in the lighting system, adjusting the capacity and weight of lifts, adopting a variable speed drive system in booster pumps, as well as using more energy efficient motors. As a result, a significant reduction in annual electricity consumption is achieved from $1032 \mathrm{kWh} /$ flat in the Client Brief January 2000 Edition to $596 \mathrm{kWh} /$ flat in 2008 [7]. In addition, the brief requires the planting of one tree for every 15 flats in a newly built public housing estate. Consequently, the annual GHG emissions caused by electricity consumption of communal building services installations have decreased from $577 \mathrm{tCO}_{2} \mathrm{e}$ to $337 \mathrm{tCO}_{2} \mathrm{e}$ (Table 4).

According to the "Model Client Brief 2010", the GHG emissions of the NH1 housing block were $215.69 \mathrm{tCO}_{2} \mathrm{e} /$ flat and $4.98 \mathrm{tCO}_{2} \mathrm{e} / \mathrm{m}^{2}$ per flat and per GFA, respectively. While the energy consumption of tenant areas is beyond the management's control, with Aspect V-“Energy consumption by tenants" being excluded, the GHG emissions were $51.88 \mathrm{tCO}_{2} \mathrm{e} /$ flat and $1.20 \mathrm{tCO}_{2} \mathrm{e} / \mathrm{m}^{2}$ per flat and per GFA, respectively (Table 4). 
Table 4. Evaluation of GHG emissions of the studied case in Hong Kong.

\begin{tabular}{|c|c|c|c|c|c|c|c|c|c|}
\hline \multicolumn{2}{|l|}{ Stage Aspect } & \multirow[t]{2}{*}{ Category } & \multirow{2}{*}{$\begin{array}{c}\text { Category } \\
\text { Type }\end{array}$} & \multicolumn{3}{|c|}{$\begin{array}{l}\text { Benchmarking Block NH1 Standard Block } \\
\text { (2000 Edition) }\end{array}$} & \multicolumn{3}{|c|}{$\begin{array}{c}\text { Benchmarking Block NH1 Standard Block (Model } \\
\text { Client Brief 2010) }\end{array}$} \\
\hline \multirow{16}{*}{$\begin{array}{l}\text { Production and } \\
\text { Construction } \\
\text { stage }\end{array}$} & \multirow{6}{*}{ I } & & & Quantity $\left(\mathrm{m}^{3}\right)$ & $\begin{array}{c}\text { Per Unit } \mathrm{CO}_{2} \mathrm{e} \\
\text { Emission } \\
\left(\mathrm{kg} / \mathrm{m}^{3}\right)\end{array}$ & $\begin{array}{l}\text { Total Emission } \\
\quad\left(\mathrm{kg} \mathrm{CO}_{2} \mathrm{e}\right)\end{array}$ & Quantity $\left(\mathrm{m}^{3}\right)$ & $\begin{array}{c}\text { Per Unit } \mathrm{CO}_{2} \mathrm{e} \\
\text { Emission } \\
\left(\mathrm{kg} / \mathrm{m}^{3}\right)\end{array}$ & $\begin{array}{l}\text { Total Emission } \\
\quad(\mathrm{kg} \mathrm{CO} 2 \mathrm{e})\end{array}$ \\
\hline & & \multirow{5}{*}{$\begin{array}{l}\text { Materials consumed } \\
\text { during construction } \\
\left(\mathrm{GHG}_{\mathrm{m}}\right)\end{array}$} & $\begin{array}{l}\text { Steel formwork for } \\
\text { superstructure }\end{array}$ & 23.3 & 15,210 & 354,393 & 22.5 & 15,210 & 342,073 \\
\hline & & & $\begin{array}{l}\text { Timber formwork for } \\
\text { superstructure }\end{array}$ & 149.8 & 962 & 144,108 & 144.6 & 962 & 139,105 \\
\hline & & & $\begin{array}{l}\text { Steel formwork for } \\
\text { substructure }\end{array}$ & 0.0 & 15,210 & 0 & 0.0 & 15,210 & 0 \\
\hline & & & $\begin{array}{l}\text { Timber formwork for } \\
\text { substructure }\end{array}$ & 3.4 & 962 & 3271 & 3.4 & 962 & 3271 \\
\hline & & & Sub Total & - & - & 501,772 & - & - & 484,449 \\
\hline & \multirow{5}{*}{ II } & \multirow{5}{*}{$\begin{array}{l}\text { Materials for structure } \\
\qquad\left(\mathrm{GHG}_{\mathrm{m}}\right)\end{array}$} & Steel for superstructure & 548.2 & 15,210 & $8,338,122$ & 433.0 & 15,210 & $6,585,930$ \\
\hline & & & Concrete for superstructure & $20,419.0$ & 426 & $8,698,494$ & $20,460.4$ & 426 & $8,716,130$ \\
\hline & & & Steel for substructure & 170.0 & 15,210 & $2,585,700$ & 170.0 & 15,210 & $2,585,700$ \\
\hline & & & Concrete for substructure & 8212.0 & 426 & $3,498,312$ & 8212.0 & 426 & $3,498,312$ \\
\hline & & & Sub Total & - & - & $23,120,628$ & - & - & $21,386,072$ \\
\hline & \multirow{4}{*}{ III } & \multirow{4}{*}{$\begin{array}{l}\text { Transportation of } \\
\text { materials }\left(\mathrm{GHG}_{\mathrm{t}}\right)\end{array}$} & Type & Quantity $\left(\mathrm{m}^{3}\right)$ & $\begin{array}{l}\text { Distance from } \\
\text { site }(\mathrm{km})\end{array}$ & $\begin{array}{l}\text { Total Emission } \\
\left(\mathrm{kg} \mathrm{CO} \mathrm{CO}_{2} \mathrm{e}\right)\end{array}$ & Quantity $\left(\mathrm{m}^{3}\right)$ & $\begin{array}{l}\text { Distance from } \\
\text { site }(\mathrm{km})\end{array}$ & $\begin{array}{l}\text { Total Emission } \\
\left(\mathrm{kg} \mathrm{CO} \mathrm{CO}_{2} \mathrm{e}\right)\end{array}$ \\
\hline & & & Steel & 741.5 & 250 & 31,531 & 625.5 & 250 & 26,598 \\
\hline & & & Timber & 153.2 & 250 & 6515 & 148.0 & 250 & 6291 \\
\hline & & & Concrete & $28,631.0$ & 20 & 97,398 & $28,672.4$ & 20 & 97,539 \\
\hline & - & - & Sub Total & - & - & 135,443 & - & - & 130,428 \\
\hline
\end{tabular}


Table 4. Cont

\begin{tabular}{|c|c|c|c|c|c|c|c|c|c|}
\hline \multicolumn{2}{|l|}{ Stage Aspect } & \multirow[t]{2}{*}{ Category } & \multirow{2}{*}{$\begin{array}{l}\text { Category } \\
\text { System }\end{array}$} & \multicolumn{3}{|c|}{$\begin{array}{l}\text { Benchmarking Block NH1 Standard Block } \\
\text { (2000 Edition) }\end{array}$} & \multicolumn{3}{|c|}{$\begin{array}{c}\text { Benchmarking Block NH1 Standard Block (Model } \\
\text { Client Brief 2010) }\end{array}$} \\
\hline \multirow{18}{*}{ Operation stage } & \multirow{9}{*}{ IV } & & & $\begin{array}{l}\text { Yearly Energy } \\
\text { Consumption } \\
(\mathrm{kWh})\end{array}$ & $\begin{array}{c}\text { Annual } \\
\text { Emission } \\
\left(\mathrm{kg} \mathrm{CO}_{2} \mathrm{e}\right)\end{array}$ & $\begin{array}{l}\text { Total Emission } \\
\text { in } 50 \text { Years } \\
\left(\mathrm{kg} \mathrm{CO}_{2} \mathrm{e}\right)\end{array}$ & $\begin{array}{l}\text { Yearly Energy } \\
\text { Consumption } \\
(\mathrm{kWh})\end{array}$ & $\begin{array}{l}\text { Annual } \\
\text { Emission } \\
\left(\mathrm{kg} \mathrm{CO}_{2} \mathrm{e}\right)\end{array}$ & $\begin{array}{c}\text { Total Emission in } \\
50 \text { Years } \\
\left(\mathrm{kg} \mathrm{CO}_{2} \mathrm{e}\right)\end{array}$ \\
\hline & & \multirow{8}{*}{$\begin{array}{l}\text { Energy consumption by } \\
\text { communal building } \\
\text { services }\left(\mathrm{GHG}_{\mathrm{o}}\right)\end{array}$} & Lighting & 538,188 & 376,732 & $18,836,580$ & 264,799 & 185,359 & $9,267,965$ \\
\hline & & & Lift & 165,783 & 116,048 & $5,802,405$ & 103,175 & 72,223 & $3,611,125$ \\
\hline & & & Security & 3793 & 2655 & 132,755 & 3793 & 2655 & 132,755 \\
\hline & & & TV & 4205 & 2944 & 147,175 & 4205 & 2944 & 147,175 \\
\hline & & & $\mathrm{A} / \mathrm{C}$ and ventilation & 17,800 & 12,460 & 623,000 & 17,800 & 12,460 & 623,000 \\
\hline & & & Fire services & 1764 & 1235 & 61,740 & 1764 & 1235 & 61,740 \\
\hline & & & Water supply & 76,972 & 53,880 & $2,694,020$ & 76,972 & 53,880 & $2,694,020$ \\
\hline & & & $\begin{array}{l}\text { Electrical distribution } \\
\text { ( } 2 \% \text { of above items })\end{array}$ & 16,170 & 11,319 & 565,954 & 9450 & 6615 & 330,756 \\
\hline & - & - & Sub Total & 824,675 & 577,273 & $28,863,629$ & 481,958 & 337,371 & $16,868,536$ \\
\hline & \multirow{8}{*}{$\mathrm{V}$} & \multirow{7}{*}{$\begin{array}{l}\text { Energy consumption by } \\
\text { tenants }\left(\mathrm{GHG}_{\mathrm{o}}\right)\end{array}$} & Energy End Use & $\begin{array}{l}\text { Yearly Energy } \\
\text { Consumption } \\
\text { (Tera joule) }\end{array}$ & $\begin{array}{l}\text { Annual } \\
\text { Emission } \\
\left(\mathrm{kg} \mathrm{CO}_{2} \mathrm{e}\right) \\
\end{array}$ & $\begin{array}{l}\text { Total Emission } \\
\text { in } 50 \text { Years } \\
\left(\mathrm{kg} \mathrm{CO}_{2} \mathrm{e}\right) \\
\end{array}$ & $\begin{array}{l}\text { Yearly Energy } \\
\text { Consumption } \\
\text { (Tera joule) }\end{array}$ & $\begin{array}{l}\text { Annual } \\
\text { Emission } \\
\left(\mathrm{kg} \mathrm{CO}_{2} \mathrm{e}\right) \\
\end{array}$ & $\begin{array}{l}\text { Total Emission in } \\
50 \text { Years } \\
\left(\mathrm{kg} \mathrm{CO}_{2} \mathrm{e}\right)\end{array}$ \\
\hline & & & $\begin{array}{l}\text { Cooking ( } 90 \% \text { gas; } \\
10 \% \text { electricity) }\end{array}$ & 4.2 & 158,997 & $7,949,854$ & 4.2 & 158,997 & $7,949,854$ \\
\hline & & & Space conditioning & 2.8 & 551,754 & $27,587,695$ & 2.8 & 551,754 & $27,587,695$ \\
\hline & & & $\begin{array}{l}\text { Hot water ( } 20 \% \text { gas; } \\
80 \% \text { electricity) }\end{array}$ & 4 & 634,835 & $31,741,738$ & 4 & 634,835 & $31,741,738$ \\
\hline & & & Lighting & 1.1 & 219,947 & $10,997,347$ & 1.1 & 219,947 & $10,997,347$ \\
\hline & & & Refrigeration & 2.2 & 421,694 & $21,084,722$ & 2.2 & 421,694 & $21,084,722$ \\
\hline & & & $\begin{array}{l}\text { Others (laundry, audiovisual } \\
\text { and miscellaneous } \\
\text { equipment) }\end{array}$ & 3.2 & 630,544 & $31,527,209$ & 3.2 & 630,544 & $31,527,209$ \\
\hline & & - & Sub Total & 17.5 & $2,617,771$ & $130,888,564$ & 17.5 & $2,617,771$ & $130,888,564$ \\
\hline
\end{tabular}


Table 4. Cont

\begin{tabular}{|c|c|c|c|c|c|c|c|c|c|}
\hline \multicolumn{2}{|l|}{ Stage Aspect } & \multirow{2}{*}{$\begin{array}{c}\text { Category } \\
\text { Renovation }\end{array}$} & \multirow{2}{*}{$\begin{array}{c}\text { Category } \\
-\end{array}$} & \multicolumn{3}{|c|}{$\begin{array}{l}\text { Benchmarking Block NH1 Standard Block } \\
\text { (2000 Edition) }\end{array}$} & \multicolumn{3}{|c|}{$\begin{array}{c}\text { Benchmarking Block NH1 Standard Block (Model } \\
\text { Client Brief 2010) }\end{array}$} \\
\hline \multirow{6}{*}{ Operation stage } & VI & & & - & - & $\begin{array}{l}\text { Total Emission } \\
\text { in } 50 \text { Years }\end{array}$ & - & - & $\begin{array}{l}\text { Total Emission in } \\
50 \text { Years }\end{array}$ \\
\hline & - & - & $\begin{array}{l}\text { Materials/components } \\
\text { replacement and transport }\end{array}$ & - & - & $2,127,938$ & - & - & $2,127,938$ \\
\hline & - & - & Sub Total & - & - & $2,127,938$ & - & - & $2,127,938$ \\
\hline & \multirow[t]{2}{*}{ VII } & \multirow[t]{2}{*}{ GHG removals $\left(\mathrm{GHG}_{\mathrm{r}}\right)$} & Tree & Quantity & $\begin{array}{c}\text { Annual } \\
\text { Emission } \\
\text { Absorption } \\
\left(\mathrm{kg} \mathrm{CO}_{2} \mathrm{e}\right)\end{array}$ & $\begin{array}{c}\text { Total } \\
\text { Absorption in } \\
50 \text { Years } \\
\left(\mathrm{kg} \mathrm{CO}_{2} \mathrm{e}\right)\end{array}$ & Quantity & $\begin{array}{c}\text { Annual } \\
\text { Emission } \\
\text { Absorption } \\
\left(\mathrm{kg} \mathrm{CO}_{2} \mathrm{e}\right)\end{array}$ & $\begin{array}{l}\text { Total Absorption } \\
\text { in } 50 \text { Years } \\
\left.(\mathrm{kg} \mathrm{CO})_{2} \mathrm{e}\right)\end{array}$ \\
\hline & & & Tree (Taller than $5 \mathrm{~m}$ ) & 0 & 0 & 0 & 53 & 1219 & 60,950 \\
\hline & - & - & Sub Total & - & - & 0 & - & - & $-60,950$ \\
\hline \multirow{5}{*}{$\begin{array}{l}\text { Demolition } \\
\text { stage }\end{array}$} & \multirow{4}{*}{ VIII } & \multirow{4}{*}{ Disposal $\left(\mathrm{GHG}_{\mathrm{d}}\right)$} & Demolition & Quantity $\left(\mathrm{m}^{3}\right)$ & $\begin{array}{l}\text { Per Unit } \mathrm{CO}_{2} \mathrm{e} \\
\text { Emission } \\
\left(\mathrm{kg} / \mathrm{m}^{3}\right)\end{array}$ & $\begin{array}{l}\text { Total Emission } \\
\qquad\left(\mathrm{kg} \mathrm{CO}_{2} \mathrm{e}\right)\end{array}$ & Quantity $\left(\mathrm{m}^{3}\right)$ & $\begin{array}{l}\text { Per Unit } \mathrm{CO}_{2} \mathrm{e} \\
\text { Emission } \\
\left(\mathrm{kg} / \mathrm{m}^{3}\right)\end{array}$ & $\begin{array}{l}\text { Total Emission } \\
\qquad\left(\mathrm{kg} \mathrm{CO}_{2} \mathrm{e}\right)\end{array}$ \\
\hline & & & Dismantling of building & 23,919 & 17 & 406,623 & 23,960 & 17 & 407,320 \\
\hline & & & Transportation & Quantity $\left(\mathrm{m}^{3}\right)$ & $\begin{array}{l}\text { Distance from } \\
\text { site }(\mathrm{km})\end{array}$ & $\begin{array}{l}\text { Total Emission } \\
\quad\left(\mathrm{kg} \mathrm{CO}_{2} \mathrm{e}\right)\end{array}$ & Quantity $\left(\mathrm{m}^{3}\right)$ & $\begin{array}{l}\text { Distance from } \\
\text { site }(\mathrm{km})\end{array}$ & $\begin{array}{l}\text { Total Emission } \\
\quad\left(\mathrm{kg} \mathrm{CO}_{2} \mathrm{e}\right)\end{array}$ \\
\hline & & & $\begin{array}{l}\text { Transportation of building } \\
\text { debris from site to } \\
\text { disposal sites }\end{array}$ & 23,919 & 26 & 105,779 & 23,960 & 26 & 105,961 \\
\hline & - & - & Sub Total & - & - & 512,402 & - & - & 513,281 \\
\hline \multicolumn{4}{|c|}{ Overrall results } & - & \multicolumn{2}{|c|}{ Total GHG Emissions } & - & \multicolumn{2}{|c|}{ Total GHG Emissions } \\
\hline & & - & & - & (tons $\mathrm{CO}_{2} \mathrm{e}$ ) & $\left(\mathrm{kg} \mathrm{CO}_{2} \mathrm{e}\right)$ & - & (tons $\mathrm{CO}_{2} \mathrm{e}$ ) & $\left(\mathrm{kg} \mathrm{CO}_{2} \mathrm{e}\right)$ \\
\hline \multirow{2}{*}{ Sum of above } & \multicolumn{3}{|c|}{ Grand total (I + II + III + IV + V + VI + VII + VIII) } & - & 186,150 & $186,150,376$ & - & 172,338 & $172,338,318$ \\
\hline & \multicolumn{3}{|c|}{$\begin{array}{l}\text { Grand total discounting tenant } \\
\text { areas }(\mathrm{I}+\mathrm{II}+\mathrm{III}+\mathrm{IV}+\mathrm{VI}+\mathrm{VII}+\mathrm{VIII})\end{array}$} & - & 55,262 & $55,261,812$ & - & 41,450 & $41,449,754$ \\
\hline \multirow{2}{*}{ Project data } & \multicolumn{3}{|c|}{ Total no. of flat } & - & 799 & - & - & 799 & - \\
\hline & \multicolumn{3}{|c|}{ Gross floor area (GFA) $\left(\mathrm{m}^{2}\right)$} & - & 34,609 & - & - & 33,078 & - \\
\hline Results & \multicolumn{3}{|c|}{$\mathrm{CO}_{2} \mathrm{e}$ emission per flat $=\mathrm{a} / \mathrm{c}$} & - & 232.98 & 232,979 & - & 215.69 & 215,693 \\
\hline- & \multicolumn{3}{|c|}{$\mathrm{CO}_{2} \mathrm{e}$ emission per flat (discounting tenant areas) $=\mathrm{b} / \mathrm{c}$} & - & 69.16 & 69,164 & - & 51.88 & 51,877 \\
\hline- & \multicolumn{3}{|c|}{$\mathrm{CO}_{2}$ e emission per GFA $\left(\mathrm{m}^{2}\right)=\mathrm{a} / \mathrm{d}$} & - & 5.38 & 5379 & - & 4.98 & 4980 \\
\hline- & \multicolumn{3}{|c|}{$\mathrm{CO}_{2} \mathrm{e}$ emission per GFA $\left(\mathrm{m}^{2}\right)$ (discounting tenant areas) $=\mathrm{b} / \mathrm{d}$} & - & 1.60 & 1597 & - & 1.20 & 1198 \\
\hline
\end{tabular}




\section{Discussion}

This study has comprehensively evaluated the GHG emissions of a concrete reinforced high-rise residential building in Hong Kong. In addition to the structural materials, the study also considered the carbon emitted from communal building services, tenants due to energy end use, renovation, building demolition, and transportation of waste materials. It can be seen that the GHG emissions of the studied case ranged from $4980 \mathrm{~kg} \mathrm{CO} 2 \mathrm{e} / \mathrm{m}^{2}$ to $5379 \mathrm{~kg} \mathrm{CO} 2 \mathrm{e} / \mathrm{m}^{2}$ (based on design). The comparison of GHG emissions among different studies in different regions per functional unit is given in Figure 4. The variation of GHG emissions is relatively high (which ranges from 1657-6276 $\mathrm{kg} \mathrm{CO}_{2} \mathrm{e} / \mathrm{m}^{2}$ ) among different studies due to the use of different structural materials (concrete, steel, wood, composite, and so forth), heating and cooling requirements for different regions based on the climate, as well as other considerations. However, the GHG evaluated in this study is in the upper range of the emissions (Figure 4). This may be due to the higher GHG emission factors for different structural materials used in Hong Kong including the long transport distance, as Hong Kong has sourced most of the construction materials from China, which have higher emission factors (Table 2) which is also supported by the previous studies. For instance, De Wolf et al. [11] estimated the GHG emissions of 200 completed buildings based on structural materials quantities in the US, and calculated the GHG emissions range from $150-600 \mathrm{~kg} \mathrm{CO}_{2} \mathrm{e} / \mathrm{m}^{2}$. However, the GHG emissions are even higher than the upper range (for structural materials) found in this study (about $686 \mathrm{~kg} \mathrm{CO}_{2} \mathrm{e} / \mathrm{m}^{2}$, Table 4).

Based on the collected data and assumptions for renovation works in Hong Kong, it is estimated that renovation contributes to $61.50 \mathrm{~kg} \mathrm{CO}_{2} \mathrm{e} / \mathrm{m}^{2}$ of the building during its considered service life (e.g., 5 years). The value is considerably higher than $45 \mathrm{~kg} \mathrm{CO} 2 \mathrm{e} / \mathrm{m}^{2}$ estimated by Ortiz-Rodríguez et al. [75] and $38 \mathrm{CO}_{2} \mathrm{e} / \mathrm{m}^{2}$ by Kumanayake and Luo [76]. However, energy efficient and low carbon refurbishments and replacement of building services can significantly help reduce the total embodied $\mathrm{CO}_{2}$ emissions of buildings [30,77].

Although the evaluation of GHG emissions was based on a single case study in this study, the sampled building is a typical design of housing blocks in Hong Kong. Comparison on the emissions of new housing development can be conducted by making references at different building life cycle stages [36]. GHG emissions can also be minimized by using environmentally-friendly materials or energy efficient appliances, lighting, heating, and cooling equipment [78]. While the tenants of public rental housing estates represent almost $28 \%$ of Hong Kong population, their behavior might have a substantial impact on energy use, especially when the building services equipment is controlled manually. Reducing material use as well as specifying the use of localized materials, recycled materials, and/or alternative low carbon material are the options available for implementation during the design stage for reducing the embodied carbon of buildings [79-86].

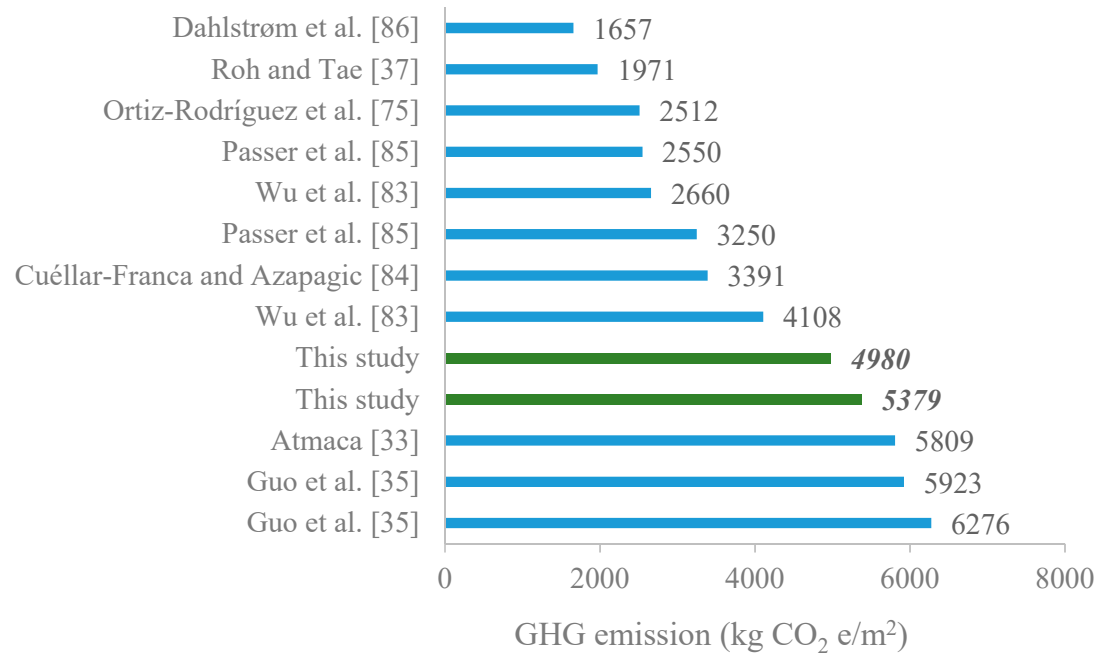

Figure 4. Comparison of GHG emissions of residential buildings. 
The contribution of cladding and other non-structural materials, including windows, doors and roof coverings, internal partitions, and internal cladding was not considered in this study. Although some of the materials used during the construction process are negligible in terms of weight, their impacts can be significant to the total impacts. For example, polyamide safety nets and aluminum are used $<0.1 \%$ by weight, but would contribute $2-3 \%$ towards the total GHG emissions [28]. These aspects were also not considered due to data unavailability despite the fact they can affect the emission inventory. In addition, carbon emissions can be expected with an anticipated growth in building activity and higher performance of buildings due to greater material use [80].

Although demolition and waste transportation were included in this study, the assessment of waste material treatments was not considered due to the different end-of-life considerations and the lack of available data. The demolition phase of buildings including demolition, waste transportation, and waste treatment contributed to about $2-5 \%$ of the total GHG emissions depending on the types of waste treatment [34,36]. However, according to Coelho and de Brito [32], GHG emissions of waste disposal could be about $65-283 \mathrm{~kg} \mathrm{CO}_{2} \mathrm{e} / \mathrm{m}^{2}$ of building (depending on the types of waste treatment). Therefore, the amount is insignificant compared to the total emissions estimated in this study ( $4980 \mathrm{~kg} \mathrm{CO}_{2} \mathrm{e} / \mathrm{m}^{2}$ ). More comprehensive investigations on the overall environmental performance of buildings by including other impact categories are desirable.

\section{Conclusions}

Environmental impacts associated with building construction, use, and end-of-life are greatly dependent on the region, climate, and type of buildings. Therefore, a case-specific assessment is important to benchmark the evaluation, as well as to reduce and mitigate the impacts from buildings. In this study, the GHG emissions from a typical high-rise residential building in Hong Kong was comprehensively evaluated using a case-specific analysis with a "cradle-to-grave" system boundary. Through this analytical regime, the GHG emissions were estimated to about $213.03 \mathrm{tCO}_{2} \mathrm{e} /$ flat and $4980 \mathrm{~kg} \mathrm{CO} 2 \mathrm{e} / \mathrm{m}^{2}$, respectively. Considering the GHG emissions over the service life of the sampled residential building, the operating energy causes over $85.82 \%$ of the emissions, whereas $12.69 \%$ for materials, $1.14 \%$ for renovation, $0.28 \%$ for end-of-life of the building, and $0.07 \%$ for other factors. Therefore, various carbon reduction measures should be attempted and evaluated such as the use of energy efficient equipment, renewable energy, recycled/recyclable materials, and eco-design by utilizing natural lighting and ventilation. Policy and decision makers should explore different low carbon construction initiatives to maximize the opportunity for emission reduction. For future work, the residential buildings including all kinds of public and private buildings should be assessed by considering the limitations of this study on their carbon emissions as well as other environmental impact indicators. Tremendous effort is required to advocate low carbon construction at various levels including building materials, building components, and the entire building through effective incentive and reward schemes. For a more sustainable future, there is an urgent call for immediate, community-wide actions to reduce GHG emissions to help combat climate change.

Author Contributions: The authors contributed equally to this manuscript. S.Y.C.M. and the Housing Department initiated and designed the Carbon and Emission Estimation model, S.T.N. and J.M.W.W. provided suggestions to improve the reliability of the model; and M.U.H. conducted further analysis based on the local data and the developed model.

Acknowledgments: The authors would like to acknowledge the Hong Kong Housing Department as the life cycle building carbon estimation method described in this paper originated from the carbon emission estimation model of the Hong Kong Housing Department.

Conflicts of Interest: The authors declare no conflicts of interest. 


\section{References}

1. IPCC. Climate Change 2014: Synthesis Report. Contribution of Working Groups I, II and III to the Fifth Assessment Report of the Intergovernmental Panel on Climate Change (IPCC); IPCC: Geneva, Switzerland, 2014.

2. Rogner, H.H.; Zhou, D.; Bradley, R.; Crabbé, P.; Edenhofer, O.; Hare, B.; Kuijpers, L.; Yamaguchi, M. Introduction. In Climate Change 2007: Mitigation. Contribution of Working Group III to the Fourth Assessment Report of the Intergovernmental Panel on Climate Change; Cambridge University Press: Cambridge, UK, 2007.

3. Stern, N.H. Stern Review on the Economics of Climate Change; HM Treasury: London, UK, 2006.

4. Ibn-Mohammed, T. Application of mixed-mode research paradigms to the building sector: A review and case study towards decarbonising the built and natural environment. Sustain. Cities Soc. 2017, 35, 692-714. [CrossRef]

5. Emami, N.; Marteinsson, B.; Heinonen, J. Environmental impact assessment of a School building in Iceland using LCA-including the effect of long distance transport of materials. Buildings 2016, 6, 46. [CrossRef]

6. Monahan, J.; Powell, J.C. An embodied carbon and energy analysis of modern methods of construction in housing: A case study using a lifecycle assessment framework. Energy Build. 2011, 43, 179-188. [CrossRef]

7. EMSD. Hong Kong Energy End-Use Data 2010; Electrical and Mechanical Services Department, Government of HKSAR: Hong Kong, China, 2010.

8. Wang, X.; Chen, D.; Ren, Z. Global warming and its implication to emission reduction strategies for residential buildings. Build. Environ. 2011, 46, 871-883. [CrossRef]

9. HKHA. Housing in Figures 2010; The Hong Kong Housing Authority, Government of HKSAR: Hong Kong, China, 2010.

10. Chen, Y.; $\mathrm{Ng}$, S.T. Factoring in embodied GHG emissions when assessing the environmental performance of building. Sustain. Cities Soc. 2016, 27, 244-252. [CrossRef]

11. De Wolf, C.; Yang, F.; Cox, D.; Charlson, A.; Hattan, A.S.; Ochsendorf, J. Material quantities and embodied carbon dioxide in structures. Proc. Inst. Civ. Eng. Eng. Sustain. 2016, 169, 150-161. [CrossRef]

12. Dong, Y.H.; $\mathrm{Ng}$, S.T. A life cycle assessment model for evaluating the environmental impacts of building construction in Hong Kong. Build. Environ. 2015, 89, 183-191. [CrossRef]

13. Peuportier, B.L.P. Life cycle assessment applied to the comparative evaluation of single family houses in the French context. Energy Build. 2001, 33, 443-450. [CrossRef]

14. Hoxha, E.; Habert, G.; Lasvaux, S.; Chevalier, J.; Roy, R.L. Influence of construction material uncertainties on residential building LCA reliability. J. Clean. Prod. 2017, 144, 33-47. [CrossRef]

15. Meijer, A.; Huijbregts, M.; Reijnders, L. Human health damages due to indoor sources of organic compounds and radioactivity in life cycle impact assessment of dwellings. Int. J. Life Cycle Assess. 2005, 10, 383-392. [CrossRef]

16. Gerilla, G.P.; Teknomo, K.; Hokao, K. An environmental assessment of wood and steel reinforced concrete housing construction. Build. Environ. 2007, 42, 2278-2784. [CrossRef]

17. Hacker, J.N.; De Saulles, T.P.; Minson, A.J.; Holmes, M.J. Embodied and operational carbon dioxide from housing: A case study on the effects of thermal mass and climate change. Energy Build. 2008, 40, 375-384. [CrossRef]

18. Li, D.Z.; Chen, H.X.; Hui, E.C.M.; Zhang, J.B.; Li, Q.M. A methodology for estimating the life-cycle carbon efficiency of a residential building. Build. Environ. 2013, 59, 448-455. [CrossRef]

19. Anand, C.K.; Amor, B. Recent developments, future challenges and new research directions in LCA of buildings: A critical review. Renew. Sustain. Energy Rev. 2017, 67, 408-416. [CrossRef]

20. Dixit, M.; Fernández-Solís, J. Need for an embodied energy measurement protocol for buildings: A review paper. Renew. Sustain. Energy Rev. 2012, 16, 3730-3743. [CrossRef]

21. Pomponi, F.; Moncaster, A. Scrutinising embodied carbon in buildings: The next performance gap made manifest. Renew. Sustain. Energy Rev. 2018, 81, 2431-2442. [CrossRef]

22. Teng, Y.; Li, K.; Pan, W.; Ng, S.T. Reducing building life cycle carbon emissions through prefabrication: Evidence from and gaps in empirical studies. Build. Environ. 2018, 132, 125-136. [CrossRef]

23. Suzuki, M.; Oka, T. Estimation of life cycle energy consumption and $\mathrm{CO}_{2}$ emission of office buildings in Japan. Energy Build. 1998, 28, 33-41. [CrossRef]

24. Seo, S.; Hwang, Y. Estimation of $\mathrm{CO}_{2}$ emissions in life cycle of residential buildings. J. Constr. Eng. Manag. 2001, 127, 414-418. [CrossRef] 
25. Bastosa, J.; Battermanb, S.A.; Freirea, F. Life-cycle energy and greenhouse gas analysis of three building types in a residential area in Lisbon. Energy Build. 2014, 69, 344-353. [CrossRef]

26. Cattarinussi, L.; Hofstetter, K.; Ryffel, R.; Zumstein, K.; Ioannidou, D.; Klippel, M. Life cycle assessment of a post-tensioned timber frame in comparison to a reinforced concrete frame for tall buildings. In Expanding Boundaries: Systems Thinking for the Built Environment, Proceedings of the Sustainable Built Environment (SBE) Regional Conference, Zürich, Switzerland, 15-17 June 2016; vdf Hochschulverlag AG an der ETH Zürich: Zürich, Switzerland, 2016; pp. 656-661.

27. Hildebrandt, J.; Hagemann, N.; Thrän, D. The contribution of wood-based construction materials for leveraging a low carbon building sector in Europe. Sustain. Cities Soc. 2017, 34, 405-418. [CrossRef]

28. Hong, J.; Shen, G.P.; Feng, Y.; Lau, W.S.; Ma, C. Greenhouse gas emissions during the construction phase of a building: A case study in China. J. Clean. Prod. 2015, 103, 249-259. [CrossRef]

29. Sandanayake, M.; Lokuge, W.; Zhang, G.; Setunge, S.; Thushar, Q. Greenhouse gas emissions during timber and concrete building construction-A scenario based comparative case study. Sustain. Cities Soc. 2018, 38, 91-97. [CrossRef]

30. Almeida, M.; Ferreira, M. Cost effective energy and carbon emissions optimization in building renovation (Annex 56). Energy Build. 2017, 152, 718-738. [CrossRef]

31. Assefa, G.; Ambler, C. To demolish or not to demolish: Life cycle consideration of repurposing buildings. Sustain. Cities Soc. 2017, 28, 146-153. [CrossRef]

32. Coelho, A.; de Brito, J. Influence of construction and demolition waste management on the environmental impact of buildings. Waste Manag. 2012, 32, 532-541. [CrossRef] [PubMed]

33. Atmaca, A. Life-cycle assessment and cost analysis of residential buildings in South East of Turkey: Part 2-A case study. Int. J. Life Cycle Assess. 2016, 21, 925-942. [CrossRef]

34. Cho, S.-H.; Chae, C.-U. A study on life cycle $\mathrm{CO}_{2}$ emissions of low-carbon building in South Korea. Sustainability 2016, 8, 579. [CrossRef]

35. Guo, H.; Liu, Y.; Meng, Y.; Huang, H.; Sun, C.; Shao, Y. A comparison of the energy saving and carbon reduction performance between reinforced concrete and cross-laminated timber structures in residential buildings in the severe cold region of China. Sustainability 2017, 9, 1426. [CrossRef]

36. Peng, C. Calculation of a building's life cycle carbon emissions based on Ecotect and building information modeling. J. Clean. Prod. 2016, 112, 453-465. [CrossRef]

37. Roh, S.; Tae, S. An integrated assessment system for managing life cycle $\mathrm{CO}_{2}$ emissions of a building. Renew. Sustain. Energy Rev. 2017, 73, 265-275. [CrossRef]

38. Cabeza, L.F.; Rincón, L.; Vilarino, V.; Pérez, G.; Castell, A. Life cycle assessment (LCA) and life cycle energy analysis (LCEA) of buildings and the building sector: A review. Renew. Sustain. Energy Rev. 2014, 29, $394-416$. [CrossRef]

39. Pomponi, F.; Moncaster, A.M. Embodied carbon in the built environment: Management, mitigation, and reduction-What does the evidence say? J. Environ. Manag. 2016, 181, 687-700. [CrossRef] [PubMed]

40. De Wolf, C.; Pomponi, F.; Moncaster, A. Measuring embodied carbon dioxide equivalent of buildings: Areview and critique of current industry practice. Energy Build. 2017, 140, 68-80. [CrossRef]

41. Dong, Y.H.; Ng, S.T. Comparing the midpoint and endpoint approaches based on ReCiPe-A study of commercial buildings in Hong Kong. Int. J. Life Cycle Assess. 2014, 19, 1409-1423. [CrossRef]

42. Gan, V.J.L.; Cheng, J.C.P.; Lo, I.M.C.; Chan, C.M. Developing a $\mathrm{CO}_{2}$-e accounting method for quantification and analysis of embodied carbon in high-rise buildings. J. Clean. Prod. 2017, 141, 825-836. [CrossRef]

43. ISO. ISO 14040_Environmental Management: Life Cycle Assessment Principles and Framework; The International Organisation for Standardization: Paris, France, 2006.

44. ISO. ISO 14064-International Standard on Greenhouse Gases-Part 1: Specification with Guidance at the Organization Level for Quantification and Reporting of Greenhouse Gas Emissions and Removals; The International Organisation for Standardization: Geneva, Switzerland, 2006.

45. WRI/WBCSD. The Greenhouse Gas Protocol: A Corporate Accounting and Reporting Standard, Revised Edition; World Resources Institute and World Business Council for Sustainable Development: Washington, DC, USA, 2010.

46. IPCC. Climate Change 2007: The Physical Science Basis, Summary for Policy Makers; Intergovernmental Panel on Climate Change: Geneva, Switzerland, 2007. 
47. LC. Design of the New Public Housing Flats by the Hong Kong Housing Authority. Legislative Council (LC) Panel on Housing, 2015. Available online: http:/ / www.legco.gov.hk/yr14-15/english/panels/hg/papers / hg20150706cb1-1037-1-e.pdf (accessed on 22 October 2018).

48. ISO. ISO 21931-1:2010-Sustainability in Building Construction-Framework for Methods of Assessment of the Environmental Performance of Construction Works_Part 1: Buildings; The International Organisation for Standardization: Geneva, Switzerland, 2010.

49. Fieldson, R.; Rai, D.; Sodagar, B. Towards a framework for early estimation of lifecycle carbon footprinting of buildings in the UK. Constr. Inf. Q. 2009, 11, 66-75.

50. Takano, A.; Pittau, F.; Hafner, A.; Ott, S.; Hughes, M.; De Angelis, E. Greenhouse gas emission from construction stage of wooden buildings. Int. Wood Prod. J. 2014, 5, 217-223. [CrossRef]

51. HKHA. Life Cycle Assessment (LCA) and Life Cycle Costing (LCC) Study of Building Materials and Components; The Hong Kong Housing Authority, Government of HKSAR: Hong Kong, China, 2005.

52. Yan, H.; Shen, Q.P.; Fan, L.C.H.; Wang, Y.; Zhang, L. Greenhouse gas emission in building construction: A case study of One Peking in Hong Kong. Build. Environ. 2010, 45, 949-995. [CrossRef]

53. Ng, S.T.; To, C.; Li, G. Unveiling the embodied carbon of construction materials through a product-based carbon labeling scheme. Int. J. Clim. Chang. Impacts Responses 2015, 7, 1-9. [CrossRef]

54. Hammond, G.; Jones, C. Inventory of Carbon and Energy (ICE); Version 2.0; Sustainable Energy Research Team, Department of Mechanical Engineering, University of Bath: Bath, UK, 2011.

55. Jing, R.; Cheng, J.C.P.; Gan, V.J.L.; Woon, K.S.; Lo, I.M.C. Comparison of greenhouse gas emission accounting methods for steel production in China. J. Clean. Prod. 2014, 83, 165-172. [CrossRef]

56. Zhang, J.; Cheng, J.C.P.; Lo, I.M.C. Life cycle carbon footprint measurement of Portland cement and ready mix concrete for a city with local scarcity of resources like Hong Kong. Int. J. Life Cycle Assess. 2014, 19, 745-757. [CrossRef]

57. Zhang, J. Life Cycle Carbon Measurement of Hong Kong Construction Materials: Cement, Concrete and Plywood. Master's Thesis, The Hong Kong University of Science and Technology University, Hong Kong, China, 2013.

58. Morris, J. The ethics and evaluation of embodied carbon in buildings. Struct. Eng. 2008, 86, 30-34.

59. Eaton, K.J.; Amato, A. A Comparative Environmental Life Cycle Assessment of Modern Office Buildings; Steel Construction Institute: Ascot, UK, 1998.

60. Alcorn, A. Embodied energy and $\mathrm{CO}_{2}$ coefficients for New Zealand building materials. In Report Series: Centre for Building Performance Research Report; Victoria University of Wellington: Wellington, New Zealand, 2003.

61. Catalonia Institute of Construction Technology (CICT). BEDEC PR/PCT ITEC Materials Database. 2011. Available online: https:/ / en.itec.cat/database/ (accessed on 22 October 2018).

62. EMSD. Life Cycle Energy Analysis of Building Construction; Final Report of Consultancy Study; Electrical and Mechanical Services Department, Government of HKSAR: Hong Kong, China, 2006.

63. Junnila, S. Life cycle assessment of environmentally significant aspects of an office building. Nord. J. Surv. Real Estate Res. Spec. Ser. 2004, 2, 81-97.

64. EPD. Guidelines to Account for and Report on Greenhouse Gas Emissions and Removals for Buildings (Commercial, Residential or Institutional Purposes) in Hong Kong, 2010 ed.; Environmental Protection Department and the Electrical and Mechanical Services Department, Government of HKSAR: Hong Kong, China, 2010.

65. Tso, G.K.F.; Yau, K.K.W. Predicting electricity energy consumption: A comparison of regression analysis, decision tree and neural networks. Energy 2007, 32, 1761-1768. [CrossRef]

66. Wan, K.S.Y.; Yik, F.W.H. Building design and energy end-use characteristics of high-rise residential buildings in Hong Kong. Appl. Energy 2004, 78, 19-36. [CrossRef]

67. Chiang, Y.H.; Li, V.J.; Zhou, L.; Wong, F.; Lam, P. Evaluating sustainable building-maintenance projects: Balancing economic, social, and environmental impacts in the case of Hong Kong. J. Constr. Eng. Manag. 2016, 142, 06015003. [CrossRef]

68. ISO. ISO/TS 14067:2013 - Greenhouse Gases_Carbon Footprint of Products-Requirements and Guidelines for Quantification and Communication; The International Organisation for Standardization: Geneva, Switzerland, 2013.

69. Hossain, M.U.; Wu, Z.; Poon, C.S. Comparative environmental evaluation of construction waste management through different waste sorting systems in Hong Kong. Waste Manag. 2017, 69, 325-335. [CrossRef] [PubMed]

70. Nielsen, C.V. Carbon Footprint of Concrete Buildings Seen in the Life Cycle Perspective; Claus Vestergaard Nielsen of the Danish Technological Institute, Concrete Centre: Taastrup, Denmark, 2008. 
71. Schlitter, M. State-of-the-art and emerging truck engine technologies for optimized performance, emissions, and life-cycle costing. In Proceedings of the 9th Diesel Engine Emissions Reduction Conference, Newport, RI, USA, 24-28 August 2003.

72. Ortiz, O.; Castells, F.; Sonnemann, G. Sustainability in the construction industry: A review of recent developments based on LCA. Constr. Build. Mater. 2009, 23, 28-39. [CrossRef]

73. Hossain, M.U.; Poon, C.S.; Dong, Y.H.; Xuan, D. Environmental impact distribution methods for supplementary cementitious materials. Renew. Sustain. Energy Rev. 2018, 82, 597-608. [CrossRef]

74. Hossain, M.U.; Poon, C.S.; Lo, I.M.C.; Cheng, J.C.P. Comparative LCA on using waste materials in the cement industry: A Hong Kong case study. Resour. Conserv. Recycl. 2017, 120, 199-208. [CrossRef]

75. Ortiz-Rodríguez, O.; Castells, F.; Sonnemann, G. Life cycle assessment of two dwellings: One in Spain, a developed country, and one in Colombia, a country under development. Sci. Total. Environ. 2010, 408, 2435-2443. [CrossRef] [PubMed]

76. Kumanayake, R.; Luo, H. A tool for assessing life cycle $\mathrm{CO}_{2}$ emissions of buildings in Sri Lanka. Build. Environ. 2018, 128, 272-286. [CrossRef]

77. Saynajoki, A.; Heinonen, J.; Junnila, S. A scenario analysis of the life cycle greenhouse gas emissions of a new residential area. Environ. Res. Lett. 2012, 7, 034037. [CrossRef]

78. Dernie, D.; Gaspari, J. Building Envelope Over-Cladding: Impact on Energy Balance and Microclimate. Buildings 2015, 5, 715-735. [CrossRef]

79. Chau, C.K.; Hui, W.K.; Ng, W.Y.; Powell, G. Assessment of $\mathrm{CO}_{2}$ emissions reduction in high-rise concrete office buildings using different material use options. Resour. Conserv. Recycl. 2012, 61, 22-34. [CrossRef]

80. Giesekam, J.; Barrett, J.R.; Taylor, P. Construction sector views on low carbon building materials. Build. Res. Inf. 2016, 44, 423-444. [CrossRef]

81. Ng, T.S.K.; Yau, R.M.H.; Lam, T.N.T.; Cheng, V.S.Y. Design and commission a zero-carbon building for hot and humid climate. Int. J. Low-Carbon Technol. 2016, 11, 222-234. [CrossRef]

82. Colangelo, F.; Forcina, A.; Farina, I.; Petrillo, A. Life cycle assessment (LCA) of different kinds of concrete containing waste for sustainable construction. Buildings 2018, 8, 70. [CrossRef]

83. Wu, X.; Peng, B.; Lin, B. A dynamic life cycle carbon emission assessment on green and non-green buildings in China. Energy Build. 2017, 149, 272-281. [CrossRef]

84. Cuéllar-Franca, R.M.; Azapagic, A. Environmental impacts of the UK residential sector: Life cycle assessment of houses. Build. Environ. 2012, 54, 86-99. [CrossRef]

85. Passer, A.; Kreiner, H.; Maydl, P. Assessment of the environmental performance of buildings: A critical evaluation of the influence of technical building equipment on residential buildings. Int. J. Life Cycle Assess. 2012, 17, 1116-1130. [CrossRef]

86. Dahlstrøm, O.; Sørnes, K.; Eriksen, S.T.; Hertwich, E.G. Life cycle assessment of a single-family residence built to either conventional- or passive house standard. Energy Build. 2012, 54, 470-479. [CrossRef] 